Bài báo khoa học

\title{
Ứng dụng mô hình đa chỉ tiêu nhằm đánh giá nguy cơ lũ quét trong bối cảnh biến đổi khí hậu toàn cầu. Trường hợp nghiên cứu cụ thể: miền núi Tây Bắc-Việt Nam
}

\section{Dương Thị Lọi ${ }^{* *}$, Đặng Phương Lan ${ }^{1}$}

${ }^{1}$ Khoa Địa lý, Đại học Sư phạm Hà Nội; duongloi1710@gmail.com; landp@hnue.edu.vn

* Tác giả liên hệ: duongloi1710@gmail.com; Tel.: 0357120145

Ban Biên tập nhận bài: 06/11/2020; Ngày phản biện xong: 19/12/2020; Ngày đăng bài: $25 / 1 / 2021$

Tóm tắt: Lũ quét là một dạng thiên tai điển hình tại vùng núi Tây Bắc của Việt Nam, tuy nhiên việc dự báo gặp nhiều khó khăn do tính chất phức tạp của nó và tác động của biến đổi khí hậu toàn cầu. Mục đích của nghiên cứu này nhằm xác định những khu vực có nguy cơ lũ quét cao dựa vào đặc điểm thực tế của khu vực nghiên cứu bằng mô hình đa chỉ tiêu. Độ dốc, hiện trạng sử dụng đất, thành phần cơ giới đất và lượng mưa là các tiêu chí được lựa chọn và đánh trọng số tương ứng với mức độ ảnh hưởng của nó đến tiềm năng lũ quét tại khu vực nghiên cứu. Phương pháp phân tích thứ bậc AHP là phương pháp phân tích đa chỉ tiêu được dùng để xác định mối tương quan so sánh giữa các tiêu chí, từ đó xây dựng bản đồ phân vùng nguy cơ lũ quét. Theo đó, khu vực nghiên cứu được phân thành năm cấp: khu vực có nguy cơ rất thấp, khu vực có nguy cơ thấp, khu vực có nguy cơ trung bình, khu vực có nguy cơ cao và khu vực có nguy cơ rất cao. Kết quả nghiên cứu đã chỉ ra rằng, lũ quét có nguy cơ hình thành cao và rất cao ở phía bắc và đông bắc của khu vực nghiên cứu chiếm trên $15 \%$ diện tích lãnh thổ, trong đó phân bố chính ở tỉnh Lai Châu và phía đông bắc tỉnh Sơn La. Kết quả nghiên cứu là tài liệu đáng tin cậy cho công tác phòng chống thiên tai và quản lý tài nguyên môi trường vùng Tây Bắc.

Từ khóa: Lũ quét; Mô hình quyết định đa chỉ tiêu; Miền núi Tây Bắc; AHP.

\section{Mở đầu}

Lũ quét là một trong những loại thảm họa thiên nhiên phổ biến nhất ở Việt Nam. Nó được coi như "kẻ giết người số một" liên quan tới thời tiết [1]. Số lượng các sự kiện lũ quét đã tăng đáng kể trong vài thập kỷ qua và gây ra nhiều tác động tiêu cực đến kinh tế, xã hội và môi trường. Lũ quét thường xảy ra ở vùng núi Việt Nam trong mùa mưa. Thiệt hại do lũ quét hàng năm ước tính khoảng từ 25 tỷ đến 200 tỷ đồng. Đặc biệt, theo báo cáo của Việt Nam tại cuộc họp cấp cao Asean lần thứ 10 diễn ra tại Tokyo của Nhật Bản năm 2012 đã thống kê rằng: chỉ trong thời gian từ năm 2000 đến năm 2009 đã xảy ra khoảng 96 trận lũ quét gây thiệt hại lớn với hơn 880 người mất tích và trên 1500 người thương, cuốn trôi và làm ngập hàng nghìn căn nhà và hoa màu [2]. Hầu như năm nào cũng có hàng chục trận lũ quét xảy ra ở miền núi của Việt Nam. Lũ quét thường xuất hiện bất ngờ, mực nước dâng cao với tốc độ lớn kèm theo trượt lở đất, sức tàn phá lớn, diễn ra trong thời gian ngắn nên rất khó dự đoán [3]. Số lượng các trận lũ quét với cường độ lớn tại khu vực Tây Bắc có xu hướng tăng trong những năm gần đây. Theo thống kê từ Văn Phòng Thường trực Ban chỉ đạo Trung ương về Phòng chống thiên tai, chỉ tính riêng đợt lũ xảy ra từ ngày 1-6/8/2017 tại khu vực Tây Bắc đã gây thiệt hại nặng nề. Cụ thể, có tới 25 người thiệt mạng rải rác các tỉnh, 15 người mất tích, 25 
người bị thương; nhiều nhà cửa và hoa màu bị cuốn trôi, các công trình công cộng bị phá hủy nghiêm trọng. Tổng thiệt hại vật chất ước tính trên 940 tỷ đồng.

Cùng với sự phát triển của khoa học công nghệ, những hiểu biết và nghiên cứu sâu về lũ quét đã tăng lên nhanh chóng trong những năm gần đây, nhưng hầu hết các nghiên cứu tập trung vào việc mô tả quá trình lũ quét dựa trên số liệu đo đạc được từ các trạm khí tượng và thủy văn [4-6]. Một số nghiên cứu đã áp dụng mô hình thủy lực trong nghiên cứu lũ quét điển hình như mô hình MIKE FLOOD, HEC-RAS, WMS [7-9], theo đó các số liệu đo đạc trực tiếp từ các trạm khí tượng thủy văn được đưa vào các mô hình nhằm tái hiện hiện trạng lũ quét, đồng thời đưa ra các kịch bản lũ quét nhằm dự báo và phòng tránh nguy cơ lũ quét tại các khu vực nghiên cứu. Việc áp dụng các mô hình thủy lực đem lại tính trực quan cao, tuy nhiên phương pháp này đòi hỏi một hệ thống cơ sở dữ liệu chi tiết từ các trạm đo để làm nhân tố đầu vào, mang tính mô phỏng, nên rất khó áp dụng tại khu vực miền núi Việt Nam, nơi mà có địa hình hiểm trở, cơ sở hạ tầng yếu kém và thiếu hụt nghiêm trọng các trạm cảnh báo thiên tai.

Trong nghiên cứu ngày, sự tích hợp giữa giữa công cụ GIS và mô hình quyết định đa chỉ tiêu (Multiple Criteria Decision Making - MCDM) được áp dụng để xác định những khu vực nhạy cảm với lũ quét. Mô hình này đã được ứng dụng ở nhiều quốc gia trên thế giới và đã đem lại hiệu quả cao với hơn 7.000 kết quả nghiên cứu được tìm thầy trên website của sciencedirect [10-12]. Ở Việt Nam, số lượng các nghiên cứu áp dụng phương pháp này chưa nhiều. Thống kê từ Science Direct chỉ ra rằng có 83 kết quả được tìm kiếm có áp dụng MCDM từ năm 1995 đến 2019 đến từ Việt Nam. Hầu hết các nghiên cứu ở Việt Nam, phương pháp này chủ yếu được sử dụng để đánh giá thích nghi sinh thái cây trồng hoặc phục vụ cho xây dựng và quy hoạch đô thị. Những nghiên cứu liên quan tới MCDM phục vụ cho thiên tai có rất ít, tuy nhiên cũng có một số công trình mang lại hiệu quả cao [13-15]. Trong số phương pháp phân tích đa chỉ tiêu, tiến trình phân tích thứ bậc (Analytic Hierarchy Process- AHP) kết hợp với chỉ số lũ quét tiềm năng (Flash Flood Potential Index - FFPI) được sử dụng khá phổ biến để đánh giá nguy cơ lũ quét tại khu vực miền núi của Việt Nam [13-17, 22-23]. Theo đó ngoài bốn yếu tố chính là độ dốc, hiện trạng sử dụng đất, loại đất và lớp phủ thực vật như chỉ số FFPI gốc của Smith [18], một số yếu tố mới được đưa thêm vào để phù hợp với thực trạng địa bàn nghiên cứu tại Việt Nam như thành phần cơ giới đất, mật độ sông suối [22], chỉ số ẩm ướt địa hình, mật độ các điểm trượt lở, tổng lượng mưa cực đại năm [16], độ tàn che [17], xã hội [13]. AHP được sử dụng khá hiệu quả để đánh giá trọng số tương quan giữa các yếu tố, nhằm xác định các yếu tố có ảnh hưởng lớn tới tiềm năng lũ quét tại địa bàn nghiên cứu. Mối tương quan này phụ thuộc vào tình hình thực tế tại địa bàn nghiên cứu, trong một số trường hợp độ dốc và lượng mưa được đánh giá là yếu tố có ảnh hưởng lớn nhất tới nguy cơ lũ quét [13,16], độ dốc, hiện trạng sử dụng đất [22], hoặc chúng có thể được đánh giá tương đương nhau [17]. Theo đó, các đặc điểm trước sự kiện của khu vực nghiên cứu như yếu tố độ dốc, yếu tố thuộc về khí hậu, hiện trạng sử dụng đất, mật độ lớp phủ thực vật... sẽ được lựa chọn là các thông số đầu vào vào trong mô hình để đánh giá. Do đây là các yếu tố tự nhiên sẵn có và tương đối ổn định, do vậy việc đánh giá sẽ có tính chính xác cao và đáng tin cậy. Hơn nữa, tại khu vực miền núi của Việt Nam, địa hình hiểm trở và thiếu hụt nghiêm trọng hệ thống cảnh báo thiên tai sớm, nên những nghiên cứu mang tính dự báo là hết sức cần thiết cho việc phòng chống thiên tai tại địa phương. Các trọng số tương ứng với các tiêu chí được đưa ra dựa vào vai trò thúc đẩy của nó đối với sự hình thành lũ quét tại khu vực nghiên cứu. Mục đích của nghiên cứu này nhằm đánh giá tiềm năng và nguy cơ lũ quét tại khu vực miền núi Tây Bắc của Việt Nam bằng cách xây dựng các chỉ tiêu đánh giá dựa vào đặc điểm khu vực nghiên cứu. Từ đó đề xuất các giải pháp nhằm phòng tránh và giảm thiểu thiệt hại do lũ quét gây ra tại khu vực miền núi Việt Nam. 


\section{Phương pháp nghiên cứu}

\subsection{Khu vục nghiên cứu}

Tây Bắc là một khu vực nổi bật trên bản đồ địa hình Việt Nam, bao gồm 4 tỉnh Điện Biên, Lai Châu, Sơn La và Hòa Bình. Đây là khu vực được coi là vùng núi cao đồ sộ bậc nhất của đất nước, kéo dài từ vĩ độ $19^{\circ} 05^{\prime} \mathrm{B}$ đến $22^{\circ} 58^{\prime} \mathrm{B}$. Phạm vi của vùng được giới hạn từ hữu ngạn sông Hồng, giáp với Trung Quốc ở phía Bắc có đường biên giới dài $310 \mathrm{~km}$. Phía Nam ngăn cách với Bắc Trung Bộ bởi thung lũng sông Cả. Phía đông giáp tiểu vùng Đông Bắc (thuộc vùng Trung du và miền núi Bắc $B$ ộ), phía đông nam giáp đồng bằng Bắc Bộ và khu vực đồng bằng Thanh-Nghệ-Tĩnh. Phía Tây giáp Lào với đường biên giới dài $560 \mathrm{~km}$ (Hình 1). Vị trí địa lý tạo nhiều cơ hội để các tỉnh thuộc khu vực Tây Bắc có thể giao lưu hợp tác phát triển kinh tế-văn hóa-xã hội với các tỉnh, các vùng kinh tế phát triển lân cận, hoặc với các quốc gia giáp ranh thông qua cửa khẩu, là cầu nối hàng hóa quan trọng giữa nước ta với các tỉnh phía tây nam Trung Quốc và thượng Lào. Tuy nhiên do địa hình chủ yếu là núi cao hiểm trở, giao thông đi lại bất tiện lại thường xuyên chịu ảnh hưởng rất lớn bởi thiên tai, trong đó nổi bật là ảnh hưởng của lũ quét nên việc phát triển kinh tế và nâng cao chất lượng cuộc sống còn găp nhiều khó khăn [19].

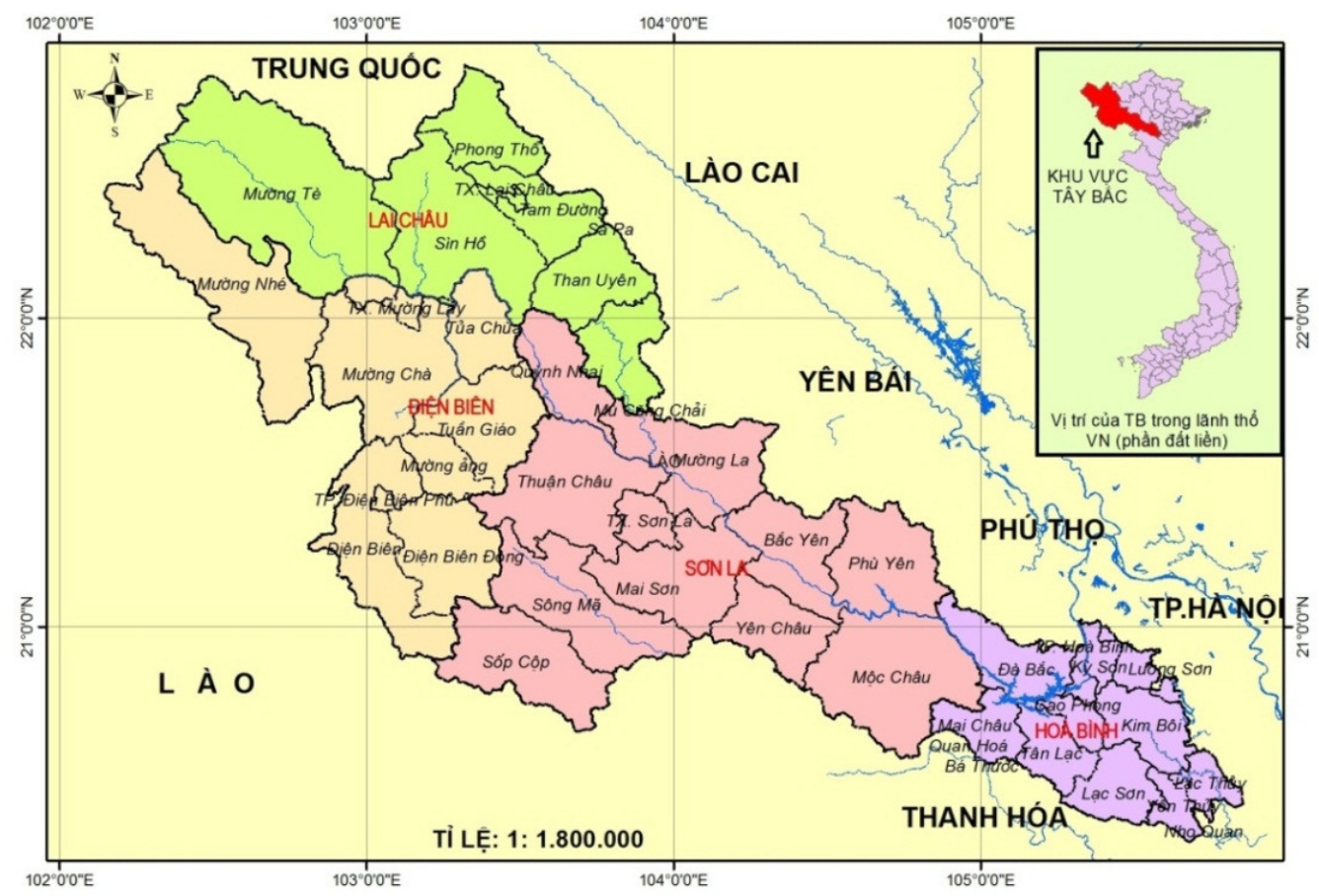

Hình 1. Vị trí và phạm vi khu vực nghiên cứu.

\subsection{Dũ liệu nghiên cúu}

Việc lựa chọn các nhân tố đóng vai trò quan trọng trong phân tích quyết định đa chỉ tiêu. Trong nghiên cứu này, các tiêu chỉ được lựa chọn dựa trên cơ sở ảnh hưởng của nó đến nguy cơ lũ quét trong khu vực nghiên cứu. Các yếu tố được cân nhắc bao gồm độ dốc, thành phần cơ giới đất, hiện trạng sử dụng đất và lượng mưa. Chi tiết được mô tả như trong bảng 1 .

Bảng 1. Dữ liệu nghiên cứu.

\begin{tabular}{clll}
\hline STT & \multicolumn{1}{c}{ Loại dữ liệu } & \multicolumn{1}{c}{ Tỉ lệ } & \multicolumn{1}{c}{ Nguồn } \\
\hline 1 & Dũ liệu hành chính các tỉnh thuộc vùng & $1: 1000000$ & Nhà xuất bản Tài nguyên - môi \\
& Tây Bắc & & trường và bản đồ Việt Nam \\
\hline
\end{tabular}




\begin{tabular}{|c|c|c|c|}
\hline STT & Loại dũ̃ liệu & Tỉ lệ & Nguồn \\
\hline 2 & Dữ liệu DEM (Digital Elevation Model) & $\begin{array}{l}\text { Mô hình số độ cao, độ } \\
\text { phân giải 30m }\end{array}$ & $\begin{array}{l}\text { Website: } \\
\text { https://earthexplorer.usgs.gov/ }\end{array}$ \\
\hline 3 & Dữ liệu lượng mưa trung bình năm & 1: 1000000 & $\begin{array}{l}\text { Sở Tài nguyên - môi trường các } \\
\text { tỉnh Tây Bắc }\end{array}$ \\
\hline 4 & Dữ liệu thành phần cơ giới đất & 1: 1000000 & $\begin{array}{l}\text { Sở Tài nguyên - môi trường các } \\
\text { tỉnh Tây Bắc }\end{array}$ \\
\hline 5 & Dữ liệu hiện trạng sử dụng đất & 1: 1000000 & $\begin{array}{l}\text { Sở Tài nguyên - môi trường các } \\
\text { tỉnh Tây Bắc }\end{array}$ \\
\hline
\end{tabular}

\subsection{Phuơng pháp nghiên cứu}

Quá trình ra quyết định thường bao gồm 5 giai đoạn chính: Xác định vấn đề, thiết lập các tiêu chí và tạo ra lựa chọn thay thể, lựa chọn tiêu chí, đánh giá tiêu chuẩn, lựa chọn phương pháp đa tiêu chí phù hợp và cuối cùng là xếp các giải pháp thay thế. Các bước thực hiện được tóm tắt như hình 2 .

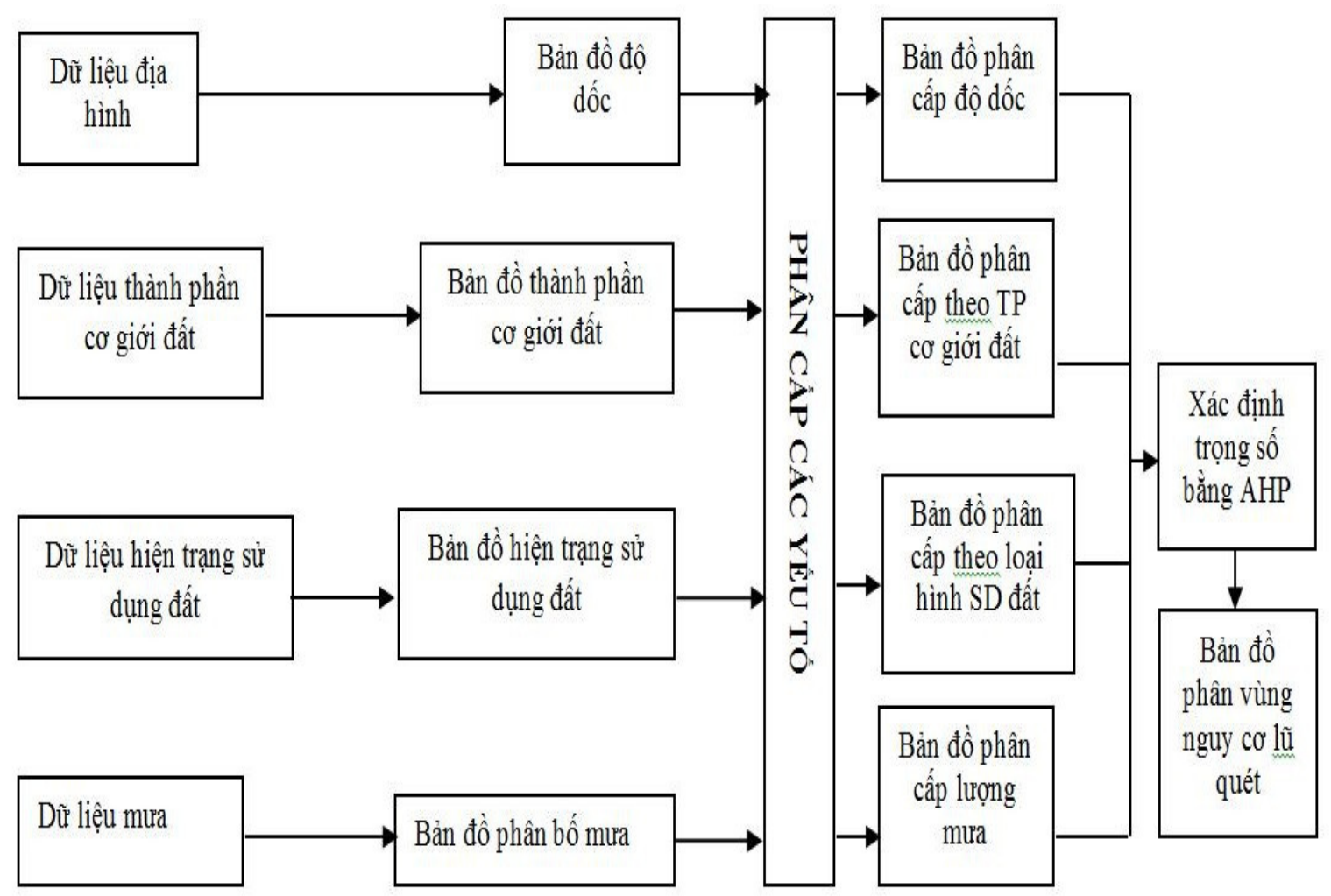

Hình 2. Quy trình thực hiện.

\subsubsection{Xây dựng các tiêu chí đánh giá}

a) Phân cấp độ dốc

Độ dốc địa hình, các kiểu hình thái sườn là những yếu tố quyết định, hướng dòng chảy và thời gian tập trung nước [20] điều này gây ảnh hưởng trực tiếp đến nguy cơ hình thành lũ quét. Các nghiên cứu đã chỉ ra rằng, tốc độ dòng chảy sẽ trở nên nhanh hơn với độ dốc tăng $3 \%$ và đạt tốc độ lớn nhất nếu độ dốc trên $30 \%$ [20 -22]. Theo đó, với độ dốc lớn trên $30 \%$ sẽ được gán giá trị 10 và các giá trị giảm dần tương ứng với từng cấp độ dốc. Phân cấp độ dốc được thực hiện như bảng 2 . 
Bảng 2. Phân cấp độ dốc.

\begin{tabular}{cccc}
\hline Độ dốc (\%) & $\begin{array}{c}\text { Phân cấp ảnh hưởng } \\
\text { của độ dốc }\end{array}$ & Độ dốc $(\%)$ & $\begin{array}{c}\text { Phân cấp ảnh hưởng } \\
\text { của độ dốc }\end{array}$ \\
\hline Từ 3 đến 6 & 1 & Từ 18 đến 21 & 6 \\
Từ 6 đến 9 & 2 & Từ 21 đến 24 & 7 \\
Từ 9 đến 12 & 3 & Từ 24 đến 27 & 8 \\
Từ 12 đến 15 & 4 & Từ 27 đến 30 & 9 \\
Từ 15 đến 18 & 5 & Trên 30 & 10 \\
\hline
\end{tabular}

b) Phân cấp thành phần cơ giới đất

Dữ liệu đất được sử dụng để xây dựng bản đồ phân cấp thành phần cơ giới đất. Cơ sở để phân chia các cấp dựa trên mức độ bở rời của đất và được quyết định bởi tỉ lệ thành phần của các hạt sét, cát và limon. Sự sắp xếp và kích thước của các hạt trọng đất sẽ ảnh hưởng trực tiếp đến khả năng giữ nước và thấm nước từ đó ảnh hưởng đến tốc độ dòng chảy và lượng nước bị giữ lại trong đất càng lớn thì khả năng hình thành dòng chảy bề mặt càng giảm [3]. Trong nghiên cứu này, dựa vào đặc điểm thực tế của thành phần cơ giới đất và các nghiên cứu khác [22-24] các giá trị được gán như bảng 3 . Theo đó, 13 loại đất điển hình trong khu vực nghiên cứu được phân chia thành các nhóm đất cơ bản, khu vực núi đá và đất xói mòn là khu vực có nguy cơ lũ quét cao nhất, tiếp đến là khu vực có thành phần sét chiếm tỉ lệ cao, khu vực có thành phần cát kết nguy cơ lũ quét thấp.

Bảng 3. Phân cấp thành phần cơ giới đất.

\begin{tabular}{|c|c|c|c|}
\hline STT & Loại đất & Nhóm đất & $\begin{array}{l}\text { Phân cấp thành } \\
\text { phần cơ giới đất }\end{array}$ \\
\hline 1 & Đất đá bột điển hình & Đất đá bột (cát kết đến thịt nhẹ) & 2 \\
\hline 2 & Đất glây chua & Đất glây chua (Thịt pha sét) & 7 \\
\hline 3 & Đất mùn Alit trên núi & Đất mùn Alit trên núi (Thịt pha sét) & 8 \\
\hline 4 & Đất nâu đỏ & \multirow{2}{*}{ Nhóm đất đỏ (Sét pha thịt) } & \multirow{2}{*}{9} \\
\hline 5 & Đất nâu vàng & & \\
\hline 6 & Đất phù sa & \multirow{3}{*}{$\begin{array}{l}\text { Nhóm đất phù sa } \\
\text { (Cát pha đến thịt nhẹ) }\end{array}$} & \multirow{3}{*}{4} \\
\hline 7 & Đất phù sa chua & & \\
\hline 8 & Đất phù sa glây & & \\
\hline 9 & Đất xám feralit & Nhóm đất xám (Sét đến thịt pha & \multirow{2}{*}{6} \\
\hline 10 & Đất xám mùn trên núi & sét) & \\
\hline 11 & Đất xói mòn mạnh trơ sỏi đá & Núi đá và đất xói mòn & 10 \\
\hline 12 & Núi đá & & \\
\hline 13 & Sông hồ & Sông hồ & 1 \\
\hline
\end{tabular}

c) Phân cấp hiện trạng sử dụng đất

Hiện trạng sử dụng đất không những làm thay đổi đặc tính vật lý của đất mà còn thay đổi cả hiện trạng lớp phủ, địa hình mặt đất. Dưới tác động của con người cùng các hoạt động sản xuất bề mặt lớp phủ thay đổi, theo đó tại những nơi có mật độ thực vật cao thì nguy cơ lũ quét thấp và ngược lại những nơi mật độ lớp phủ thực vật thấp như đất ở đô thị, khu vực đất trống thì nguy cơ xảy ra lũ cao. Việc sử dụng bản đồ hiện trạng sử dụng đất không chỉ giúp xác định 
hiện trạng lớp phủ mà còn thấy được tác động của yếu tố con người lên việc hình thành lũ quét. Từ đó có những giải pháp phù hợp nhằm hạn chế tối đa những tác động tiêu cực của con người trong việc thúc đẩy nguy cơ lũ quét tại khu vực nghiên cứu. Bản đồ hiện trạng sử dụng đất tỉ lệ 1: 1000000 năm 2015 do Sở tài nguyên môi trường cung cấp được sử dụng để xác định hiện trạng bề mặt, theo đó khu vực Tây Bắc gồm có 9 loại cơ bản: đất trồng cây công nghiệp lâu năm, đất trồng cây hằng năm, đất rừng tự nhiên, đất rừng trồng, đất trồng lúa, đất đồng cỏ và cây bụi, đất ở, sông hồ và núi đá. Dựa vào khả năng thấm hút nước bề mặt tương ứng với từng loại [22-24], các giá trị được gán tương ứng như bảng 4.

Bảng 4. Phân cấp hiện trạng sử dụng đất.

\begin{tabular}{clc}
\hline TT & \multicolumn{1}{c}{ Loại đất } & Phân cấp hiện trạng sử dụng đất \\
\hline 1 & Đất trồng cây công nghiệp lâu năm & 5 \\
2 & Đất trồng cây hằng năm & 6 \\
3 & Đất rừng tự nhiên & 2 \\
4 & Đất rừng trồng & 3 \\
5 & Đất trồng lúa & 4 \\
6 & Đất đồng cỏ và cây bụi & 8 \\
7 & Đất ở & 9 \\
8 & Sông hồ & 1 \\
9 & Núi đá & 10 \\
\hline
\end{tabular}

d) Phân cấp lượng mưa

Lũ quét xảy ra ở những nơi có lượng mưa với cường độ lớn, tập trung kết hợp với địa hình dốc. Bên cạnh đó, lũ quét thường xuất hiện ở địa bàn hẹp, trong khi dự báo khí tượng thủy văn là trên quy mô lớn. Rađa quét gặp đồi núi trập trùng, trong điều kiện thời tiết mưa lũ gặp nhiều khó khăn, chỉ có thể dự báo trước khi lũ xảy ra một thời gian rất ngắn nên không có nhiều ý nghĩa. Động lực trực tiếp gây ra lũ quét là mưa, do đó việc nghiên cứu phương pháp tính toán mưa khả năng tạo lũ quét là rất cần thiết, nhằm dự báo khu vực có nguy cơ lũ quét cao. Khi cảnh báo lũ quét cần xem xét dữ liệu lượng mưa một ngày lớn nhất. Từ nguồn dữ liệu lượng mưa một ngày lớn nhất được đo tại các trạm, với sự trợ giúp của công cụ GIS, thuật toán nội suy địa lý được thực hiện để tạo ra bản đồ đẳng trị mưa một ngày lớn nhất. Dựa trên kết quả có được, tác giả tiến hành phân cấp nguy cơ tạo ra lũ quét trên địa bàn nghiên cứu. Theo đó lượng mưa một ngày lớn nhất của khu vực Tây Bắc dao động từ 100-200 mm và được phân chia đều thành 10 cấp (bảng 5), trong đó khu vực có lịch sử một ngày lớn nhất trên $180 \mathrm{~mm}$ được gán giá trị 10, tương đương với mức nguy cơ cao nhất và ngược lại, những khu vực mà lượng mưa ngày lớn nhất dưới $100 \mathrm{~mm}$ được gán trị bằng 1 , tương ứng với khu vực ít có nguy cơ xảy ra lũ quét do mưa nhất.

Bảng 5. Phân cấp lượng mưa.

\begin{tabular}{cc}
\hline Lượng mưa (mm) & Phân cấp lượng mưa \\
\hline$<100$ & 1 \\
$100-110$ & 2 \\
$110-120$ & 3 \\
$120-130$ & 4 \\
$130-140$ & 5 \\
$140-150$ & 6 \\
$150-160$ & 7 \\
\hline
\end{tabular}




\begin{tabular}{cc}
\hline Lượng mưa $(\mathbf{m m})$ & Phân cấp lượng mưa \\
\hline $160-170$ & 8 \\
$170-180$ & 9 \\
$>180$ & 10 \\
\hline
\end{tabular}

\subsubsection{Xác định khu vực nguy cơ lũ quét}

MCDM (Multi Criteria Decision Making - Ra quyết định đa tiêu chi) nhằm mục đích chọn ra thứ tốt nhất từ một bộ các lựa chọn thay thế trên cơ sở của việc đánh giá nhiều tiêu chí. Bản đồ phân vùng nguy cơ lũ quét được xác định dựa trên kết quả chồng xếp các bản đồ thành phần trong môi trường GIS. AHP (Analytical Hierarchy Process) là một phương pháp tính toán trọng số áp dụng cho các bài toán ra quyết định đa tiêu chuẩn được lựa chọn để xây dựng bản đồ kết quả. Phương pháp này cung cấp một thứ tự sắp xếp của những quyết định và nhờ vào nó mà ta tìm được một quyết định cuối cùng hợp lý nhất. $\mathrm{AHP}$ được phát triển bởi Thomas L. Saaty [25] và đã được mở rộng và bổ sung cho đến nay. Hệ số của ma trận được tính từ điểm của việc so sánh cặp của các thành phần, các giá trị chỉ số và các loại chỉ tiêu thông qua các ý kiến chuyên gia (Bảng 6). Sau đó, các trọng số liên quan đến các thành phần của ma trận được xử lý bằng cách sử dụng thuật toán AHP.

Bảng 6. Bảng xếp hạng các mức độ so sánh cặp trong thuật toán AHP.

\begin{tabular}{|c|c|c|}
\hline Mức quan trọng & Giá trị số & Giải thích \\
\hline Quan trọng như nhau & 1 & \multirow{2}{*}{ Hai hoạt động có đóng góp ngang nhau } \\
\hline Quan trọng như nhau cho đến vừa phải & 2 & \\
\hline Quan trọng vừa phải & 3 & \multirow{2}{*}{$\begin{array}{l}\text { Kinh nghiệm và sự phán quyết có sự ưu tiên } \\
\text { vừa phải cho một hoạt động }\end{array}$} \\
\hline Quan trọng vừa phải đến hơi quan trọng hơn & 4 & \\
\hline Hơi quan trọng hơn & 5 & \multirow{2}{*}{$\begin{array}{l}\text { Kinh nghiệm và sự phán quyết có sự ưu tiên } \\
\text { mạnh cho một hoạt động }\end{array}$} \\
\hline Hơi quan trọng hơn đến rất quan trọng & 6 & \\
\hline Rất quan trọng & 7 & \multirow{2}{*}{ Một hoạt động rất quan trọng } \\
\hline Rất quan trọng đến vô cùng quan trọng & 8 & \\
\hline Vô cùng quan trọng & 9 & Được ưu tiên ở mức cao nhất có thể \\
\hline
\end{tabular}

Tóm tắt các bước giải bài toán AHP:

Bước 1: Xác định các yếu tố liên quan và thiết lập thứ bậc quan trọng

Bước 2: Phân hạng và so sánh các yếu tố. Thiết lập ma trận so sánh cặp của sự đóng góp hay tác động của yếu tố lên tiêu chuẩn của mức thứ bậc phía trên của nó. Một nửa của ma trận so sánh là số nghịch đảo của nửa kia. Yếu tố bên tay trái của ma trận sẽ được so sánh với yếu tố ở hàng trên cùng của ma trận.

Bước 3: Tính giá trị trọng số.

Bước 4: Kiểm tra tính nhất quan của các cặp so sánh cặp.

Dựa vào các bước tính toán AHP kết hợp với ý kiến từ 20 chuyên gia thuộc các lĩnh vực liên quan, ma trận so sánh được thành lập. Theo đó, độ dốc được xác định là yếu tố có mức ảnh hưởng lớn nhất tới nguy cơ lũ quét tại khu vực Tây Bắc, thứ hai là yếu tố lượng mưa, tiếp đó là hiện trạng sử dụng đất. Thành phần cơ giới đất được xem là yếu tố ít ảnh hưởng nhất tới nguy cơ lũ quét. Theo lẽ thông thường, mưa được coi là yếu tố quan trọng để hình thành lũ quét, nhưng trên thực tế, việc mưa kết hợp với các yếu tố khác (địa hình, kết cấu đất...) để tạo ra dòng chảy lũ quét quan trọng hơn. Bên cạnh đó, nhiều nơi mưa rất lớn, nhưng lại không có lũ quét, nếu không có yếu tố bổ sung với nó. Hiện trạng sử dụng đất đóng vai trò quan trọng trong việc thúc đẩy hoặc làm giảm nhẹ ảnh hưởng của lũ quét trong địa bàn nghiên cứu. Tại những khu vực có lớp phủ thực vật dày đặc, phương thức canh tác khoa học sẽ hạn chế phần 
nào những tác động tiêu cực của lũ quét. Ngược lại tại những khu vực lớp phủ thực vật bị tàn phá, bề mặt đất trơ sỏi đá, cùng với lối cánh tác du canh du cư phổ biến ở đồng bào miền núi Tây Bắc như hiện nay sẽ khiến cho nguy cơ lũ quét tăng lên. Mối quan hệ so sánh giữa các yếu tố được mô tả trong bảng 7 . Trong bước tiếp theo, giá trị ma trận được chuẩn hóa (bảng 8) và xác định mức độ nhất quán, hợp lý của các cặp so sánh. Phương pháp AHP đo sự nhất quán thông qua tỉ số nhất quan $(\mathrm{CR})$, giá trị tỷ số nhất quán tốt nhất là nhỏ hơn 1 , nếu lớn hơn cần thực hiện lại (công thức 1,2 ). Theo đó trong trường hợp này, tỉ số nhất quán $\mathrm{CR}=0,04$. Trọng số của các yếu tố độ dốc, lượng mưa, hiện trạng sử dụng đất và thành phần cơ giới đất trong nghiên cứu này lần lượt là $0,56,0,26,0,12$ và 0,06 .

Bảng 7. Bảng so sánh giữa các yếu tố.

\begin{tabular}{cccccc}
\hline & Độ dốc & LM & HTSDD & TPCGD & Tổng \\
\hline Độ dốc & 1,00 & 3,00 & 5,00 & 7,00 & 16,00 \\
LM & 0,33 & 1,00 & 3,00 & 5,00 & 9,33 \\
HTSDD & 0,2 & 0,33 & 1,00 & 3,00 & 4,53 \\
TPCGĐ & 0,14 & 0,20 & 0,33 & 1,00 & 1,68 \\
Total & 2 & 5 & 9 & 16 & \\
\hline
\end{tabular}

Bảng 8. Ma trận chuẩn hóa.

\begin{tabular}{ccccccc}
\hline & Độ dốc & LM & HTSDD & TPCGĐ & Tổng & Trung bình \\
\hline Độ dốc & 0,60 & 0,66 & 0,54 & 0,44 & 2,23 & 0,56 \\
LM & 0,20 & 0,22 & 0,32 & 0,31 & 1,05 & 0,26 \\
HTSDD & 0,12 & 0,07 & 0,11 & 0,19 & 0,49 & 0,12 \\
TPCGĐ & 0,09 & 0,04 & 0,04 & 0,06 & 0,23 & 0,06 \\
\hline
\end{tabular}

Trong đó HTSDD là hiện trạng sử dụng đất; TPCGĐ là thành phần cơ giới đất; LM là lượng mưa.

Ma trận về ý kiến của các chuyên gia có thể được xác định bằng tỉ số nhất quán (Consistency ratio-CR):

$$
\mathrm{CR}=\mathrm{CI} / \mathrm{RI}
$$

Trong đó CI là chỉ số nhất quán (Consistency Index); RI là chỉ số ngẫu nhiên (Random Index). RI được xác định từ bảng cho sẵn (Bảng 9).

$$
\mathrm{CI}=(\lambda \max -\mathrm{n}) /(\mathrm{n}-1)
$$

Trong đó $\lambda_{\max }$ là giá trị riêng của ma trận so sánh; $\mathrm{n}$ là số nhân tố.

Bảng 9. Chỉ số ngẫu nhiên ứng với số nhân tố (RI) [20].

\begin{tabular}{llllllllllllllll}
\hline $\mathbf{n}$ & $\mathbf{1}$ & $\mathbf{2}$ & $\mathbf{3}$ & $\mathbf{4}$ & $\mathbf{5}$ & $\mathbf{6}$ & $\mathbf{7}$ & $\mathbf{8}$ & $\mathbf{9}$ & $\mathbf{1 0}$ & $\mathbf{1 1}$ & $\mathbf{1 2}$ & $\mathbf{1 3}$ & $\mathbf{1 4}$ & $\mathbf{1 5}$ \\
\hline $\mathrm{RI}$ & 0,00 & 0,00 & 0,58 & 0,90 & 1,12 & 1,24 & 1,32 & 1,41 & 1,45 & 1,49 & 1,51 & 1,48 & 1,56 & 1,57 & 1,59 \\
\hline
\end{tabular}

\section{Kết quả và thảo luận}

\subsection{Xây dụng các bản đồ thành phần}

\subsubsection{Bản đồ phân cấp độ dốc}

Dựa vào kết quả nội suy từ dữ liêu DEM khu vực Tây Bắc, ta thấy địa hình cao nhất ở phía phía Bắc và phía Đông Bắc của vùng, độ cao giảm dần về phía trung tâm và phía Nam, 
hình thành nên những khu vực có độ dốc lớn, tạo điều kiện dòng chảy tập trung nhanh, dẫn đến nguy cơ xảy ra lũ quét là khá cao (Hình 3).
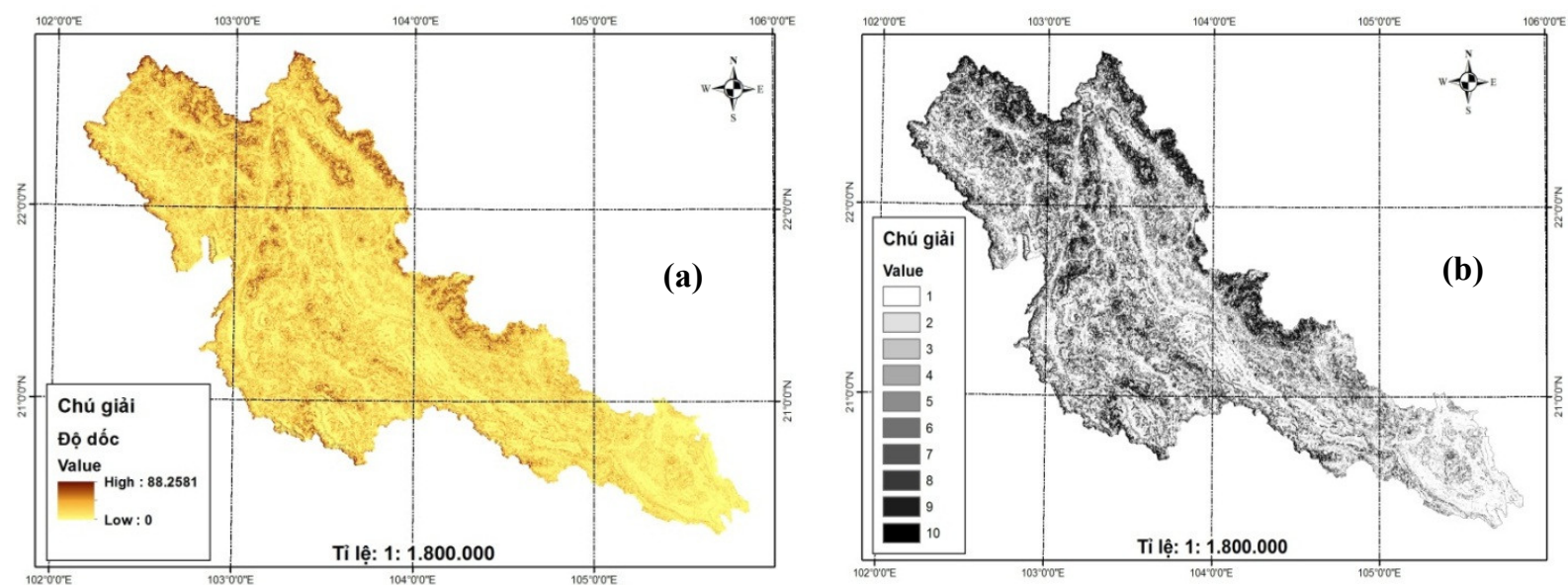

Hình 3. (a) Bản đồ độ dốc, (b) Bản đồ phân cấp độ dốc.

\subsubsection{Bản đồ phân cấp thành phần cơ giới}

Đất có nhiều sét, sẽ cực kì dính và dẻo khi gặp nước. Với điều kiện mưa bình thường để duy trì sự sống, đặc điểm đất này thích hợp cho việc giữ nước để cung cấp đủ nước cho cây, ít bị rửa trôi hơn các loại đất khác. Tuy nhiên, đây vừa là thuận lợi vừa là hạn chế khi xảy ra mưa lớn, do đất sét rất chặt, hạt nhỏ nên rất khó thấm và thoát nước. Do đó đất rất dễ bị úng khi mưa và nứt nẻ khi khô hạn. Trên cơ sở thực tế và qua phân tích bản đồ cho thấy, khu vực Tây Bắc có đặc điểm tài nguyên đất điển hình cho thổ nhưỡng của miền núi. Diện tích đất xám feralit và đất xám mùn trên núi rất cao, chiếm khoảng $80 \%$ diện tích đất của vùng. Những loại đất này có thành phần cơ giới từ sét đến thịt pha sét (Hình $4 \mathrm{a}$ ). Trên cơ sở ứng dụng công nghệ GIS và thiết lập các giá trị như phần phương pháp đã đề cập, ta có bản đồ phân cấp thành phần cơ giới đất như hình $4 \mathrm{~b}$.
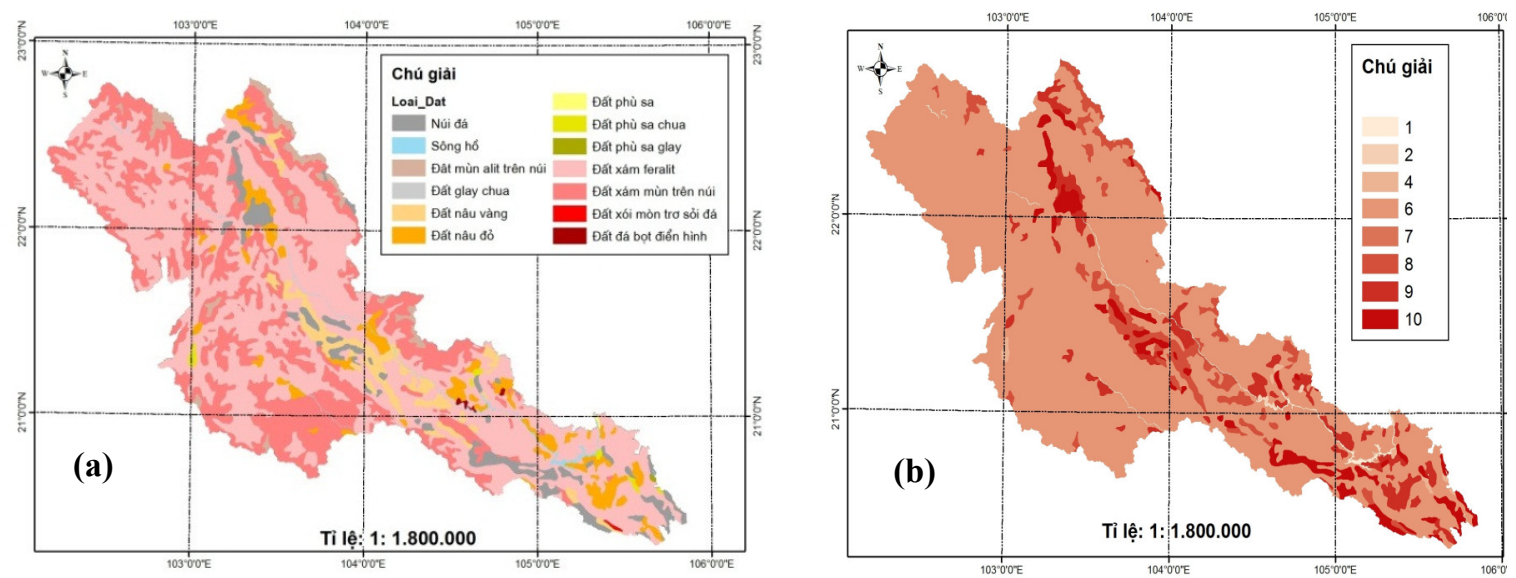

Hình 4. (a) Bản đồ loại đất, (b) Bản đồ phân cấp thành phần cơ giới đất.

\subsubsection{Bản đồ phân cấp hiện trạng sử dụng đất}

Diện tích đất trồng cây công nghiệp hàng năm, đồng cỏ và cây bụi vẫn chiếm diện tích lớn trong khu vực lên đến 70\%. Đây không phải một điểm mạnh cho việc phòng chống nguy cơ do lũ quét. Trong khi đó, diện tích rừng tự nhiên chỉ 870621,1 ha (chiếm 23,5\%), khá thấp so với một khu vực chủ yếu là đồi núi như Tây Bắc (Hình $5 \mathrm{a}$ ). Do vậy, việc tích cực phủ xanh bề mặt đất bằng rừng và che phủ những vùng đất trống đồi trọc là rất cần thiết nhằm giảm 
thiểu nguy cơ lũ quét tại khu vực này. Kết quả phân cấp bản đồ hiện trạng sử dụng đất được thể hiện như hình $5 \mathrm{~b}$. Theo đó, khu vực núi đá bở rời, địa hình dốc với lớp phủ bị tàn phá là nơi có nguy cơ xảy ra lũ quét cao nhất được gán giá trị 10 , khu vực rừng tự nhiên có nguy cơ thấp nhất được giá trị 1 .
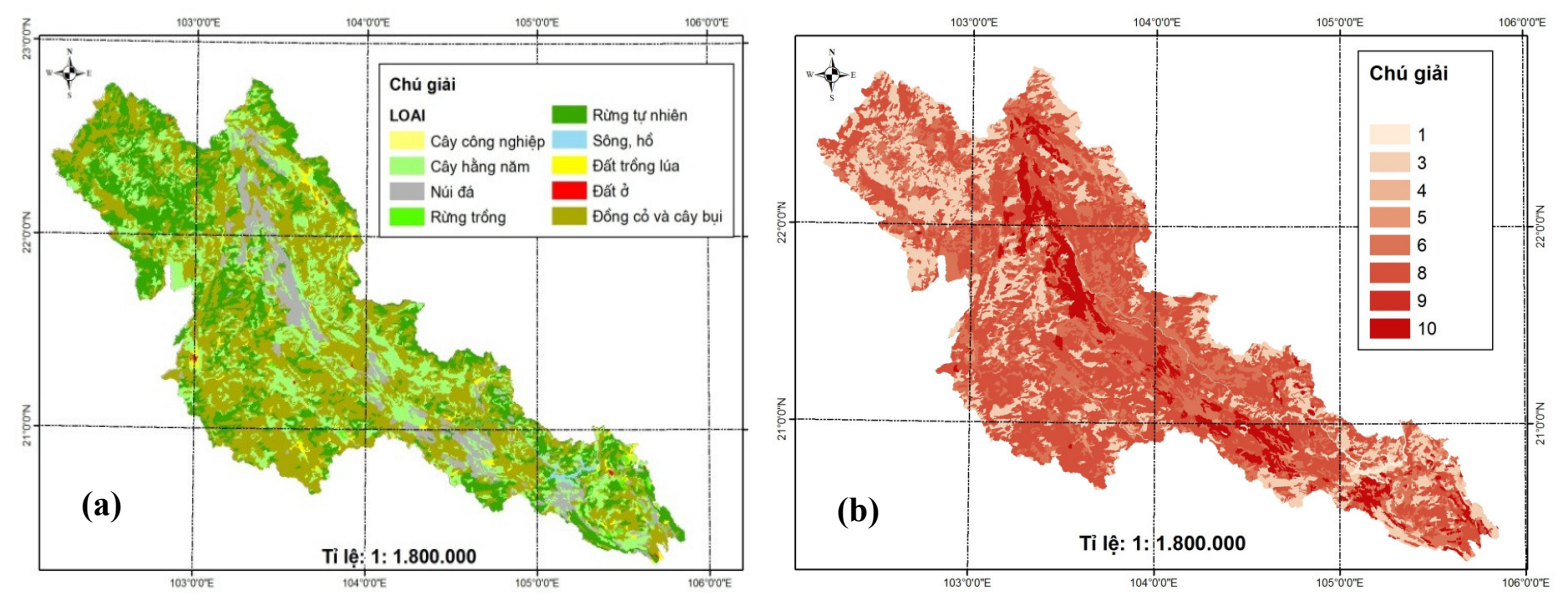

Hình 5. (a) Bản đồ hiện trạng sử dụng đất, (b) Bản đồ phân cấp hiện trạng sử dụng đất.

\subsubsection{Bản đồ phân cấp mưa}

Tây Bắc nằm trong vùng khí hậu nhiệt đới ẩm gió mùa, lượng mưa trong năm được gây ra bởi nhiều nguyên nhân như mưa đối lưu, mưa do bão và áp thấp nhiệt đới. Các cơn mưa này có đặc điểm, mưa lớn, kích thước hạt lớn và mưa trong nhiều giờ. Kết hợp với địa hình dốc của Tây Bắc, rất dễ xảy ra các trận lũ quét không mong muốn. Việc dự báo là hết sức khó khăn vì đây là một khu vực rộng, lại chủ yếu là đồi núi, do đó việc nghiên cứu phương pháp tính toán mưa, khả năng tạo ra lũ quét là rất cần thiết. Theo kết quả thu thập được từ chuỗi dữ liệu tại các trạm đo, lượng mưa một ngày lớn nhất dao động từ $84,6 \mathrm{~mm}$ đến 203,9 mm. Từ bản đồ có thể thấy lượng mưa một ngày lớn nhất phân bố theo hướng cao ở phía bắc (Trạm Mường Tè: $204 \mathrm{~mm}$, Trạm Sìn $\mathrm{H}: 194 \mathrm{~mm}$ ) và giảm dần về phía trung phía phía nam (Trạm Hòa Bình: 114 mm, Trạm Mai Châu: $105 \mathrm{~mm}$ ), thấp nhất khu vực trung tâm (Trạm Sơn La: 93 mm, Trạm Sông Mã: 85 mm) (Hình 6a). Bản đồ phân cấp lượng mưa được xây dựng dựa trên kết quả nội suy từ bản đồ lượng mưa một ngày lớn nhất và được mô tả như hình $6 \mathrm{~b}$. Dữ liệu mưa một ngày lớn nhất được triết xuất từ chuỗi dữ liệu đo đạc từ năm 1975 đến 2005. Theo đó, nguy cơ xảy ra lũ quét do tác động của mưa được phân thành 10 cấp. Khu vực phía bắc thuộc tỉnh Lai Châu được xác định có nguy cơ cao nhất, đây đồng thời là những địa điểm núi cao đón gió, các địa điểm ở trung tâm trùng với vùng thung lũng ít mưa nhất.
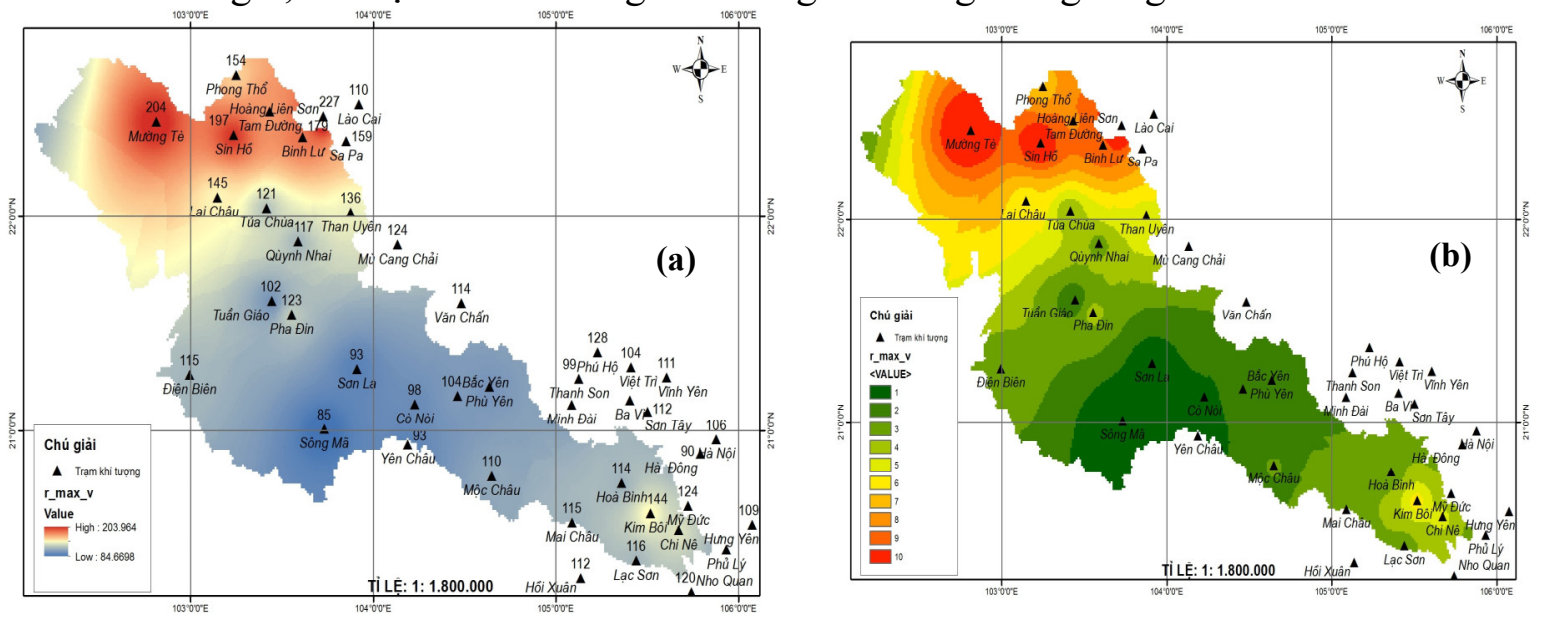

Hình 6. (a) Bản đồ nội suy mưa một ngày lớn nhất, (b) Bản đồ phân cấp lượng mưa. 


\subsubsection{Bản đồ phân vùng nguy cơ lũ quét}

Dựa vào kết quả từ các bản đồ các yếu tố thành phần và giá trị trọng số được xác định ở trên, bản đồ phân vùng nguy cơ lũ quét được thành lập (Công thức 1). Các lớp dữ liệu raster sẽ được chồng xếp bằng công cụ GIS. Theo đó, miền giá trị kết quả sẽ phân bố từ 0 đến 10 và bản đồ phân vùng nguy cơ lũ quét được phân chia đều theo phương pháp trung bình cộng thành năm cấp tương ứng với các giá trị dưới 2 , từ 2 đến 4 , từ 4 đến 6 , từ 6 đến 8 và từ 8 đến 10 (Bảng 10), gồm có: khu vực có nguy cơ rất cao, khu vực có nguy cơ cao, khu vực có nguy cơ trung bình, khu vực có nguy cơ thấp, khu vực có nguy cơ rất thấp.

$$
A=\frac{0.56(\mathrm{X} 1)+0.26(\mathrm{X} 2)+0.12(\mathrm{X} 2)+0.06(\mathrm{~K} 4)}{n}
$$

Trong đó $\mathrm{A}$ là nguy cơ lũ quét; $\mathrm{X}_{1}$ là độ dốc; $\mathrm{X}_{2}$ là lượng mưa, $\mathrm{X}_{3}$ là hiện trạng sử dụng đất, $\mathrm{X}_{4}$ là thành phần cơ giới đât; $\mathrm{n}$ là tổng giá trị của trọng số (trong trường hợp này $\mathrm{n}=1$ ).

Bảng 10. Phân cấp nguy cơ xuất hiện lũ quét.

\begin{tabular}{cl}
\hline Giá trị & \multicolumn{1}{c}{ Nguy co xuất hiện } \\
\hline Dưới 2 & Khu vực có nguy cơ rất thấp \\
Từ 2 đến 4 & Khu vực có nguy cơ thấp \\
Từ 4 đến 6 & Khu vực có nguy cơ trung bình \\
Từ 6 đến 8 & Khu vực có nguy cơ cao \\
Từ 8 đến 10 & Khu vực có nguy cơ rất cao \\
\hline
\end{tabular}

Kết quả nghiên cứu chỉ ra rằng, hầu hết các địa phương trong khu vực Tây Bắc đều nằm trong diện có nguy cơ lũ quét ở mức thấp và trung bình. Trong đó, khu vực có nguy cơ lũ quét thấp chiếm $54.6 \%$, nguy cơ trung bình chiếm $24.4 \%$. Chỉ có một phần diện tích khá nhỏ trên 60 nghìn ha thuộc khu vực có nguy cơ lũ quét rất thấp được phân bố phía nam huyện Sông Mã, Sốp Cộp, Mộc Châu (Sơn La), một phần diện tích huyện Lương Sơn, Kỳ Sơn, Thành phố Hà Bình (Hòa Bình) (Bảng 11).

Trên toàn khu vực nghiên cứu, có thể thấy lũ quét có nguy cơ hình thành rất cao ở phía bắc và đông bắc, tương ứng với khu vực có địa hình có cao, độ dốc lớn, trong đó phân bố chính ở tỉnh Lai Châu và phía đông bắc tỉnh Sơn La. Một số huyện có nguy cơ lũ quét rất cao như Phong Thổ, Mường Tè, Sìn Hồ, Tam Đường (tỉnh Lai Châu); rải rác ở một số nơi thuộc huyện Mường $\mathrm{La}$ (tỉnh Sơn $\mathrm{La}$ ). Càng về phía nam và tây nam của vùng Tây Bắc, nguy cơ lũ quét ngày càng giảm. Các khu vực có nguy cơ lũ quét thấp hơn nằm rải rác như khu vực tiếp giáp giữa huyện Mường Tè và Mường Nhé, thành phố Điện Biên và một số huyện thuộc tỉnh Hòa Bình (Kì Sơn, Lương Sơn, Cao Phong, Đà Bắc) (Hình 7).

Bảng 11. Phân cấp nguy cơ lũ quét khu vực Tây Bắc.

\begin{tabular}{lcc}
\hline & Diện tích (ha) & Tỉ lệ (\%) \\
\hline Khu vực có nguy cơ rất thấp & 60224,5 & 1,7 \\
Khu vực có nguy cơ thấp & 1989529,6 & 54,6 \\
Khu vực có nguy cơ trung bình & 891209,7 & 24,4 \\
Khu vực có nguy cơ cao & 477837,7 & 13,1 \\
Khu vực có nguy cơ rất cao & 227043,6 & 6,2 \\
\hline
\end{tabular}




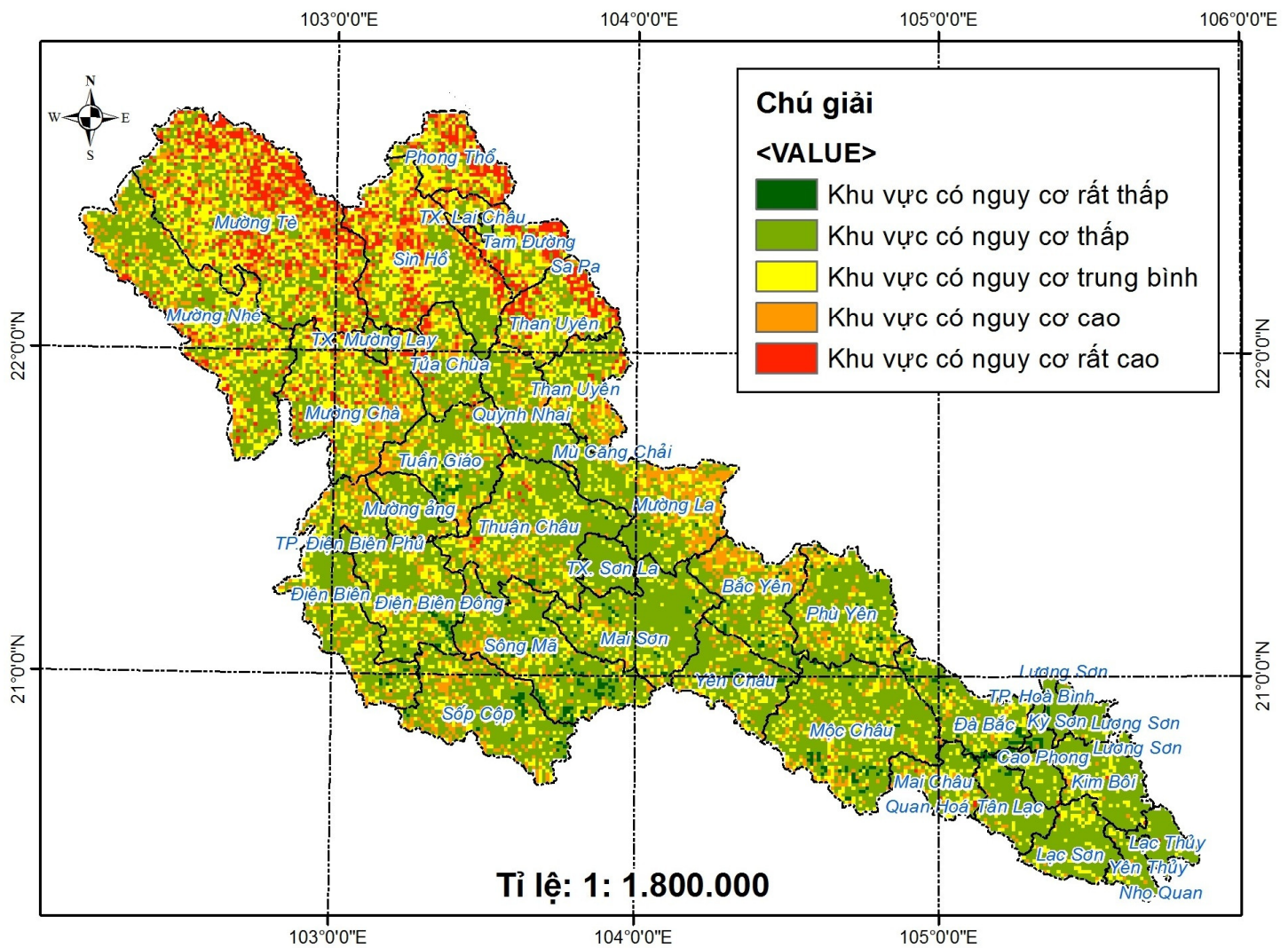

Hình 7. Bản đồ phân vùng nguy cơ lũ quét khu vực Tây Bắc.

Kết quả dự báo khả năng lũ quét xảy ra tại tỉnh thuộc vùng Tây Bắc là tương đối phù hợp với kết quả điều tra về lũ quét như sau:

Tại Lai Châu, ngày 25/6/2018, theo thông tin từ Văn phòng Ban chỉ huy phòng chống thiên tai và tìm kiếm cứu nạn tỉnh Lai Châu, lũ quét đã cướp đi sinh mạng của 11 người dân, 11 người khác mất tích cùng nhiều người bị thương. Trong số các nạn nhân mất tích xã Noong Hẻo (huyện Sìn Hồ) có 5 người bị lũ cuốn, 1 người ở xã Mường Thít (huyện Than Uyên), 1 người ở xã Sơn Bình (huyện Tam Đường) và 1 người ở xã Hua Bum (huyện Nậm Nhùn). Ngày 23/9/2020, lũ quét do mưa lớn tiếp tục xảy ra ở các huyện thuộc tỉnh Lai Châu. Lượng mưa phổ biến từ $20-60 \mathrm{~mm} / 24 \mathrm{~h}$, có nơi trên $80 \mathrm{~mm} / 24 \mathrm{~h}$. Đặc biệt nguy cơ lũ quét, sạt lở đất rất cao tại các huyện: Mường Tè, Sìn Hồ, Tam Đường; nguy cơ lũ quét, sạt lở đất cao tại các huyện: Than Uyên, Tân Uyên, Nậm Nhùn, Phong Thổ và TP. Lai Châu. Theo thống kê, những khu vực này cũng đã từng xảy ra lũ quét đặc biệt nghiêm trọng trong những năm 1990, 1998, 2000. Từ năm 2010 đến nay, hầu như năm nào cũng xảy ra tình trạng lũ quét gây ra thiệt hại rất nghiêm trọng về người và tài sản, đồng thời tổn thương đến môi trường.

Tại cầu Nậm Pay, xã Mùn Chung (Tuần Giáo, Điện Biên) vào ngày 28/8/2018, mưa lớn từ đêm $27 / 8$ đã gây ra lũ quét cao khoảng 2-3 m, chảy tràn qua đường tỉnh 129 khiến các phương tiện không thể lưu thông được. Gần đây nhất, ngày 17/8/2020, lũ quét xảy ra ở xã Nậm Nhừ (Nầm Pồ, Điện Biên). Lũ quét cũng xảy ra ở Sơn La và gây thiệt hại lớn trong những năm 1991, 2015, 2017, tập trung chủ yếu ở các xã thuộc huyện Mường La.

\section{Kết luận}

Việc lựa chọn các nhân tố và đánh giá trọng số cho các yếu tố đóng vai trò quan trọng trong nghiên cứu. Việc thay đổi vai trò của chúng sẽ ảnh hưởng đáng kể đến kết quả nghiên cứu, do đó cần cần nhắc các yếu tố ngày một cách cẩn thận. Việc đánh giá các trọng số cần dựa trên tình hình thực tế của khu vực nghiên cứu cũng như ý kiến từ các chuyên gia nhằm đảm bảo độ chính xác của kết quả nghiên cứu. 
Mặc dù lũ quét là một hiện tượng từ tự nhiên, nhưng nó lại bị tác động bởi các yếu tố con người. Việc khai thác sản xuất, xây dựng các công trình, đốt nương làm rẫy của các đồng bào dân tộc nơi đây có ảnh hưởng không nhỏ đến việc làm tăng nguy cơ lũ quét. Do đó việc nâng cao trình độ dân trí, hạn chế các tác động tiêu cực đến môi trường và lớp phủ rừng là giải pháp rất quan trọng đối với khu vực Tây Bắc nhằm giảm thiểu ảnh hưởng do lũ quét gây ra.

Theo đó, các khu vực có nguy cơ lũ quét cao trong khu vực nghiên cứu trùng khớp là những nơi có độ dốc địa hình lớn. Chẳng hạn khu vực, tỉnh Lai Châu, phía đông và đông bắc là dãy Hoàng Liên Sơn cao và đồ sộ, phía bắc là các dãy núi cao ven biên giới Việt Trung. Hơn nữa, với địa hình cao, các khu vực núi này có vai trò như bức chắn địa hình, gây mưa cho khu vực Tây Bắc. Trên hết, khu vực Lai Châu và đông bắc Sơn La, nằm giáp ranh nên thường xảy ra mưa lớn, kết hợp với độ dốc địa hình, sinh ra lũ quét. Ngược lại, các khu vực khác ngoài việc phân bố ở các khu vực đồi núi có độ dốc thấp hơn, thì lượng mưa cung cấp cũng không quá lớn. Đặc biệt là khu vực trung tâm của tiểu vùng Tây Bắc, bao gồm một số khu vực thuộc địa phận các huyện của tỉnh Sơn La và Điện Biên. Càng xuống phía nam, tức vùng hạ lưu sông Đà, khu vực tỉnh Hòa Bình có nguy cơ xảy ra lũ quét thấp nhất, do đây có độ dốc không quá lớn, lượng mưa trung bình, thảm thực vật lại phân bố đa dạng. Cụ thể, đây là khu vực phát triển nhiểu mô hình vườn - rừng trong khu vực, khi kết hợp phát triển trồng cây ăn quả với trồng rừng. Kết quả từ mô hình đa chỉ tiêu phù hợp với tình hình thực tế của khu vực nghiên cứu.

Tuy nhiên nghiên cứu còn tồn tại một vài hạn chế do sự thiếu hụt về cơ sở dữ liệu. Cụ thể, dữ liệu lượng mưa một ngày lớn nhất mới chỉ thu thập được trong khoảng thời gian 30 năm (1975 đến 2005), khoảng thời gian này là chưa đủ thuyết phục để kết luận tính quy luật của một hiện tượng có tính ồn định như khí hậu. Đặc biệt, sự biến đổi khí hậu và những diễn biến thất thường xảy ra khá rõ nét trong những thập niên gần đây. Bên cạnh đó, việc dừng lại ở các đối chiếu so sánh kết quả nghiên cứu với các thông tin thu thập từ các bài báo tản mác cũng phần nào làm ảnh hưởng đến mức độ đáng tin cậy của kết quả. Việc cần có những công trình nghiên cứu chuyên sâu làm đối chiếu so sánh là rất cần thiết. Những hạn chế này sẽ được nhóm tác giả tiếp tục hoàn thiện trong những nghiên cứu tiếp theo.

Đóng góp của tác giả: Xây dựng ý tưởng nghiên cứu: D.T.L., Đ.P.L.; Lựa chọn phương pháp nghiên cứu: D.T.L.; Xử lý số liệu: D.T.L.; Viết bản thảo bài báo: D.T.L., Đ.P.L.; Chỉnh sửa bài báo: D.T.L.

Lò̀i cảm ơn: Bài báo là kết quả của Đề tài NCKH cấp Trường được tài bởi Trường Đại học Sư phạm Hà Nội. Mã số: SPHN19-08.

Lò̀i cam đoan: Tập thể tác giả cam đoan bài báo này là công trình nghiên cứu của tập thể tác giả, chưa được công bố ở đâu, không được sao chép từ những nghiên cứu trước đây; không có sự tranh chấp lợi ích trong nhóm tác giả.

\section{Tài liệu tham khảo}

1. Jeffrey, Z.; Kevin, D. The Flash floos potential index at WFO Des Moines, Iowa, Project at National Weather Service, National Oceanic and Atmospheric Administration, 2013. http://204.227.127.200/images/dmx/hydro/FFPI WriteUp.pdf.

2. Vietnam country report. The $10^{\text {th }}$ ASEAN \& Japan highlevel official meeting on Caring Societies, National framework and practices for socially vulnerable groups in case where natural disaster hit country, Tokyo, Japan, 2012.

3. https://www.mhlw.go.jp/bunya/kokusaigyomu/asean/2012/d1/Vietnam CountryRep ort.pdf. 
4. Nektarios, N.K.; George, P.K. Flood management and a GIS modeling method to assess flood-hazard areas - a case study. Hydrol. Sci. J. 2011, 56, 212-225.

5. Tawatchai, T.F.K. Flood-hazard assessment and riskbased zoning of a tropical Floodplain: Case study of the Yom River, Thailand. Hydrol. Sci. J. 2010, 55, 145-161.

6. Karatzas, N.N. Flood management and a GIS modeling method to assess flood-hazard areas - a case study. Hydrol. Sci. J. 2011, 56, 212-225.

7. Evangelia, G.; Chrisoula, R.; Kleomenis, K.; Christos, C. A gis-based flash flood runoff model using high-resolution DEM and meteorological data. Eur. Assoc. Remote Sens. 2013, 12, 33-43.

8. Jasper, K.; Gurtz, J.; Lang, H. Advanced Flood forecasting in Alpine watersheds by coupling meteorological observations and forecasts with a distributed hydrological model. J. Hydrol. 2002, 267, 253-254.

9. Trương, V.A.; Hoàng, T.S. Phân vùng hiểm họa lũ lụt do mưa lớn trên lục địa kết hợp với mực nước biển dâng lưu vực sông $\mathrm{Vu}$ Gia, Thu Bồn. Tạp chí Khi tương Thủy văn 2019, 705, 1-10.

10. Đỗ, T.D.; Trần, H.T. Đánh giá tác động của ngập lụt đến sử dụng đất nông nghiệp ở các huyện ven biển của tỉnh Nghệ An trong bối cảnh biến đổi khí hậu. Tạp chí Khí tuợng Thủy văn 2017, 674, 1-7.

11. Tincu, R.; Lazar, G.; Lazar, I. Modified flash flood potential index in order to estimate areas with predisposition to water accumulation. Open Geosci. 2018, 10, 593-606.

12. Wang, Y.; Hong, H.; Chen, W.; Li, S.; Pamučar, D.; Gigović, L.; Drobnjak, S.; Bui, D.T.; Duan, H. A hybrid GIS multi-criteria decision-making method for flood susceptibility mapping at Shangyou, China. Remote Sens. 2019, 11, 1-34.

13. Romulus, C.; Dieu, T.B. Identification of areas prone to flash-flood phenomena using multiple-criteria decision-making, bivariate statistics, machine learning and their ensembles. Sci. Total Environ. 2020, 712, 1-12.

14. Lê, H.T.; Nguyễn, T.H.; Nguyễn, D.L.; Nguyễn, K.L. Phân vùng nguy cơ lũ lụt tại lưu vực sông Vu Gia, tỉnh Quảng Nam bằng ứng dụng công nghệ GIS và thuật toán AHP. Tạp chí Khoa họ ĐHQGHN, Các Khoa học Trái đất và Môi trương 2013, 3, $64-72$.

15. Trần, T.P.; Phan, T.M.; Nguyễn, B.N. Sử dụng phân tích đa tiêu chí để cảnh báo nguy cơ lũ lụt tại huyện Quảng Điền, tỉnh Thừa Thiên Huế, Tạp chí khoa học và công nghệ nông nghiệp 2020, 4, 1721-1733.

16. Lê, N.N.; Nguyễn, N.T.; Lã, T.H. Tích hợp GIS và viễn thám xác định nguy cơ lũ quét lưu vực sông Năng, tỉnh Bắc Kạn. Tạp chí Khí tượng Thủy văn 2015, 5, 19-26.

17. Lại, T.A.; Nguyễn, N.T.; Phạm, X.C; Lê, N.N; Vũ, D.C. Xây dựng hệ thống cảnh báo sớm lũ quét ở vùng núi, thử nghiệm tại huyện Thuận Châu, Sơn La. Tạp chí Khoa hoc Công nghệ Việt Nam 2018, 60, 28-35.

18. Kiều, V.H.; Vũ, H.N. Úng dụng Viễn thám và GIS xây dựng bản đồ tiềm năng lũ quét tỉnh Lai Châu. Hội thảo khoa học "Khoa học Địa lý trong sụ nghiệp giáo dục 
đào tạo và phát triển kinh tế-xã hội của đất nước. NXB Đại học Su phạm, 2006, 478 -488 .

19. Smith, G. Flash flood potential: Determining the hydrologic response of FFPI basins to heavy rain by analyzing their physiographic characteristics. https://www.cbrfc. noaa.gov/papers/ffp_wpap.pdf.

20. Đặng, D.L. Địa lí tự nhiên Việt Nam 2 (Phần khu vực). NXB Đại học Sư phạm, Hà Nội, 2015.

21. Greenhill, N.B.; Peverill, K.I.; Douglas, L.A. Surface runoff losses from sloping fertilised perennial pasture in Victoria, Australia; New Zealand. J. Agric. Res. 1983, 26, 227-231.

22. Fox, D.M.; Bryan, R.B.; Price, A.G. The influence of slope angle on infiltration rate for interrill conditions. Geoderma. 1997, 80, 181-194.

23. Thinh, N.V.; Hoan, K.V.; Thanh, D.V. Úng dụng ArcGIS trong nghiên cứu và giảng dạy địa lý. NXB Đại học Sư phạm, Hà Nội, 2016.

24. Loi, D.T.; Thanh, D.V.; Huong, L.V. Detection of flash-flood potential areas using watershed characteristics: Application of Cau river watershed in Vietnam. J. Earth Sys. Sci. 2020, 129, 1-16.

25. Pei, J.S.; Yi, Y.; Jing, Z.; Jing, A.W.; Yi, G.; Guo, Y.Q. The effect of land use/cover change on surface runoff in Shenzhen Region, China. Catena 2007, 69, 31-35.

26. Saaty, R.W. The analytic hierarchy process - what it is and how it is used. Math. Model. 1987, 9, 161-176.

\title{
Application of Multi Criteria Decision Model to assess flash flood risk in the context of global climate change. A case study: Northwest mountainous region-Vietnam
}

\author{
Duong Thi Loi ${ }^{*}$, Dang Phuong Lan ${ }^{1}$ \\ ${ }^{1}$ Faculty of Geography, Hanoi National University of Education; \\ duongloi1710@gmail.com; landp@hnue.edu.vn
}

\begin{abstract}
Flash flood is a typical natural disaster in the Northwest mountainous region of Vietnam, however forecasting is difficult due to its complexity and the impacts of global climate change. The purpose of this study is to identify areas at high risk of flash floods based on the actual characteristics of the study area using a multi criteria decision model. Slope, land use, soil texture, and rainfall are selected and weighted criteria corresponding to its impact on flash flood potential in the study area. The AHP (Analytic Hierarchy Process) method is a multi-criteria analysis method used to determine the comparative correlation between the criteria, thereby building the flash flood risk zoning map. Accordingly, the study area is classified into five levels: very low risk area, low risk area, medium risk area, high risk area, and very high risk area. The research results have shown that flash floods have a very high risk of forming in the north and northeast of the study area with above $15 \%$ of the total area, of which the main distribution is in Lai Chau and northeast of Son La province. The research results are reliable documents for natural disaster prevention and environmental resource management in the Northwest.
\end{abstract}

Keywords: Flash flood; Multi Criteria Decision Model; Northwest mountainous region; AHP. 